\title{
DAMIAN KUBIK
}

Uniwersytet Jagielloński w Krakowie

Instytut Filologii Słowiańskiej

\section{O PRAWO DO RÓŻNICY1 - O POSTAWIE ZAANGAŻOWANEJ W PISARSTWIE PREDRAGA MATVEJEVICIA (SZKIC)}

Niedawna śmierć wybitnego i uznanego w Europie intelektualisty oraz człowieka kultury jakim był Predrag Matvejević (1932-2017) zmusza do innego spojrzenia na jego bogatą twórczość eseistyczną i publicystyczną oraz aktywną działalność na różnych płaszczyznach życia publicznego. Znany przede wszystkim jako piewca Śródziemnomorza, kontynuator tradycji intelektualnej Miroslava Krležy (z którym przeprowadził kultowe dziś rozmowy), a także obrońca autorów wyklętych, jak Danilo Kiš, czy politycznych dysydentów w niepodległej Chorwacji był częściej krytykowany i atakowany niż szanowany. Dorobek tego autora pochodzącego ,z Chorwacji, Jugosławii i Europy Środkowej”2 zyskuje dziś zatem znaczenie intelektualnego testamentu człowieka będącego świadkiem skomplikowanej historii tego regionu.

\section{Portret intelektualisty zaangażowanego i czlowieka kultury}

Predrag Matvejević za sprawą swojej aktywności w życiu publicznym Jugosławii począwszy od lat 70. XX wieku aż do swojej śmierci dał się poznać jako zaangażowany intelektualista, toczący ideowe boje na wielu frontach, ale również szukający porozumienia i zgody. Takie właśnie zachowanie wynikało z wyznawanych przez niego zasad i wartości, których świadectwo można znaleźć w jego tekstach. Matvejeviciowska kategoria zaanga-

${ }^{1}$ Określenia tego (za pravo na razliku - tu w przekładzie z języka słoweńskiego na chorwacki) użył wobec działalności społeczno-politycznej i kulturalnej Predraga Matvejevicia Taras Kermauner, Recenzija Matvejevićevih „Otvorenih pisama”, prev. I. Cesar, [w:] P. Matvejević, Otvorena pisma. Moralne vježbe, Zagreb 1985, s. 190. Pojawia się ono też w otwierającym książkę Otvorena pisma tekście samego Matvejevicia. Por. P. Matvejević, Slobodanu Mašiću, nezavisnom izdavaču (Zagreb, 9. V 1985), [w:] idem, Otvorena pisma, op. cit., s. 9. Wszystkie cytaty (a także pojedyncze sformułowania i terminy) zaczerpnięte z tekstów w języku chorwackim/ serbskim zamieszczam w tłumaczeniu własnym.

2 C. Magris, Filologia morza, [w:] P. Matvejević, Brewiarz śródziemnomorski, przeł. D. Ćirlić-Straszyńska, Sejny 2003, s. 8 . 
żowania, będąca właśnie nie ideowym i moralnym imperatywem, a realizowaną w publicznej działalności postawą, wywodzi się z dwóch dopełniających się źródeł: idei zaangażowania Jeana Paula Sartre’a i zasady Entschlossenheit (zdecydowania, włączenia się) Martina Heideggera. Idea zaangażowania (ideja angažmana) nie jest jedynie - jak nieco idealistycznie postrzegał to sam Matvejević - nastawieniem na zmianę świata, ale przede wszystkim gestem odrzucenia jego aktualnego (wciąż nieidealnego) stanu, innymi słowy - wyrazem niezgody na próby znalezienia się i dostosowania do tej rzeczywistości, co może prowadzić do zwykłego konformizmu. „Mjera angažmana je - pisze Matvejević njegova mogućnost stvaralačke aktualizacije"3 (Miarą zaangażowania jest możliwość jego twórczej aktualizacji).

Wartość i potrzebę kategorii zaangażowania najlepiej obrazuje zastosowane przez Matvejevicia w książce Jugoslavenstvo danas ${ }^{4}$ (Jugosłowiańskość dzisiaj, 1982) rozróżnienie dwóch postaw pisarskich wobec rzeczywistości. Pierwsza z nich, którą określa mianem između izdaje i neprijateljstva (między zdradą i wrogością), oznacza sprzeciw lub oskarżanie przez intelektualistę swojego środowiska, co naraża go tym samym na groźbę, że zostanie okrzyknięty zdrajcą bądź nieprzyjacielem. Tak pojęta krytyka automatycznie zawęża pole działania i deprecjonuje swoje podstawy. Druga z wyróźnionych postaw krytycznych između šutnje $i$ pohvale (między milczeniem i pochwałą) nie jest rozwiązaniem łatwiejszym. Pochwała dominującej, przynależnej władzy ideologii nie wymaga $\mathrm{w}$ tym przypadku wielu słów. Milczenie może być wymowne, co Matvejević ilustruje odwołaniem do milczenia Ivo Andricia i Miroslava Krležy z okresu faszystowskiej okupacji. Taka postawa nie spełnia dziś jednak swej roli, gdyż niepostrzeżenie przechodzi w konformizm.

Matvejević walczy o prawdę - za tę walkę i za tę prawdę płacił najpierw w Jugosławii, potem w Chorwacji ogromną cenę. Michel Foucault sformułował swego czasu ideę troski o prawdę, która, będąc prawdą spoza gry, stała się imperatywem europejskiej lewicy. Jest to prawda, która nigdy nie jest dana, która nie jest możliwa do uchwycenia, dzięki czemu inspiruje krytyczną teorię i buntowniczą praktykę społeczną ${ }^{5}$. Matvejević jako człowiek lewicy walczy o to, czego jeszcze nie ma, o coś, o co trzeba się głośno upominać, nie zważając na możliwe reakcje i konsekwencje ze strony tych, którzy próbują takie głosy za wszelką cenę uciszyć.

Polem jego oddziaływania w tym zakresie była i polityka, i kultura. Słuszne wydaje się stwierdzenie, że polityka jest dla niego sprawą kultury. Wszystko, co dzieje się na polu polityki, powinno opierać się na uniwersalnych standardach, więcej nawet: budować pewne kulturowo uzasadnione jakości. W tej kwestii Matvejević bliski był słoweńskiemu pisarzowi, eseiście i intelektualiście, Dragowi Jančarowi. Przyjrzyjmy się jego jakże wymownej opinii:

Polityka rozumiana w kategoriach zagadnienia kulturowego oznacza możliwość funkcjonowania systemu wartości i sensu. A sensem istnienia społeczeństwa jest nie jego upolitycznienie, lecz

${ }^{3}$ P. Matvejević, Prema novom kulturnom stvaralaštvu, II prošireno izd., Zagreb 1977, s. 116-117.

${ }^{4}$ Idem, Jugoslavenstvo danas: pitanja kulture, Zagreb 1982.

${ }^{5}$ Por. A. Ostolski, Lewica po stronie prawdy, [w:] S. Žižek, Kruchy absolut. Czyli dlaczego warto walczyć o chrześcijańskie dziedzictwo, przeł. M. Kropiwnicki, wstęp J. Kutyła, Warszawa 2009, s. 170-171. 
kultura i twórczość. Polityka jest po to, by służyć, nie zaś po to, by w świadomości każdej jednostki odciskać znamię swej zaborczej natury ${ }^{6}$.

A zatem Matvejević, podobnie jak wspomniany Jančar, postrzega kulturę jako płaszczyznę, na której powinna być ufundowana polityka i wszelkie sankcjonowane przez nią relacje i stosunki międzyludzkie. Tak pojęta kultura, która nadaje jednostce i wspólnocie tożsamość, nie może zostać zawładnięta przez polityczny i ideologiczny interes. Innymi słowy, polityka nie powinna zwyciężyć i zdominować kultury, tylko musi służyć człowiekowi na zasadach wynikających z jej istoty.

Rozumienie tych naturalnych zdawałoby się mechanizmów w obrębie społeczności obrazuje po części dokonane przez niego rozróżnienie na dwie tożsamości: tożsamość istnienia (identitet bića) i tożsamość działania (identitet činjenja), gdzie pierwszy typ żywiony mitami krwi, rasy i terytorium - bierze górę nad drugim, który te fantasmagorie transponuje we wspólnotowy projekt. Wskazać należy przy tej okazji na charakterystyczne dla tego intelektualisty przeświadczenie, że horyzontem istnienia jest tożsamość będąca efektem przynależności do określonej kultury, którą dla Matvejevicia reprezentuje cywilizacja śródziemnomorska ${ }^{7}$. Przekonywające stają się słowa:

Alternative između ,ukorijenjenosti” u biće nacije nacionalnosti (Barresov enracinement) i osjećaja „,bez-zavičajnosti” (Heimatlosigkeit, što je po Hajdegeru dio „svjetske sudbine”) izazivaju sporove, ne samo u Evropi. Žudnja za zavičajem i okrepa koju pruža „rodna gruda” ne jamče uvijek intelektualni i stvaralački probitak ${ }^{8}$.

(Możliwości pomiędzy „zakorzenieniem” w łonie narodu w formie przynależności narodowej [enracinement Barrésa] a poczuciem „bycia bez ojczyzny” [Heimatlosigkeit, co dla Heideggera stanowi część „losu świata”] wywołują konflikty nie tylko w Europie. Tęsknota za ojczyzną i siła, której dostarcza „gruda ojczystej ziemi” nie zawsze gwarantuje intelektualną i twórczą korzyść).

Za najkorzystniejsze rozwiązanie proponowane przez Matvejevicia dla Europejczyka cierpiącego z powodu burzliwej historii kontynentu, jak i nieprzystawalności jego narodowych i etnicznych tożsamości, trzeba uznać przyjęcie tożsamości kulturowej odwołującej do wspólnego dziedzictwa Śródziemnomorza. W swoich najbardziej znanych książkach, jak Mediteranski brevijar (Brewiarz śródziemnomorski, 1987), Druga Venecija (Inna Wenecja, 2002) czy nawet - w będącej swego rodzaju kontynuacją obu z nich, zwłaszcza zaś pierwszej - Kruh naš (Chleb nasz, 2009), podejmuje wędrówkę w czasie i przestrzeni w poszukiwaniu zapomnianych źródeł naszej cywilizacji. Dzieła te, znane i cenione na całym świecie, zrodziły się jako sublimacja duchowych dążeń i pragnień Matvejevicia.

${ }^{6}$ D. Jančar, Eseje, przeł. J. Pomorska, wyb. i wstęp K. Czyżewski, Sejny 1999, s. 192-193.

7 Ten istotny aspekt pisarstwa Predraga Matvejevicia został tu przywołany jedynie hasłowo, w kontekście zagadnienia, o którym mowa w niniejszym artykule. Szerzej na ten temat piszę w następujących publikacjach: O potrzebie tożsamości w czasach nowoczesnych: tożsamość kulturowa Zbigniewa Herberta i Predraga Matvejevicia, „Pamiętnik Słowiański” 2009, t. LIX, z. 1, s. 33-53 oraz O „pragnieniu źródła” - judeochrześcijańskie i śródziemnomorskie korzenie Europy w eseistyce Predraga Matvejevicia, [w:] Źródła humanistyki europejskiej, t. 3, red. K. Korus, Kraków 2010, s. 15-28.

${ }^{8}$ P. Matvejević, Mit nacije i sablasti nacionalizma. Nacionalna kultura i mondijalizacija, ,Rukovet: časopis za književnost, umetnost i kulturu" 2006, br. 1-3, s. 34. 
Pisząc je - często na marginesie swojej pracy akademickiej i działalności publicznej - spotykał się bezpośrednio i pośrednio z innymi ludźmi, reprezentującymi różne narody, kultury, religie, poglądy:

Morza nie odkrywamy sami i nie patrzymy na nie tylko swoimi oczyma. Postrzegamy je również tak, jak widzieli je inni, na fotografiach, które nam zostawili, w opowieściach, jakie od nich usłyszeliśmy. Poznajemy morze i jednocześnie rozpoznajemy. [...] Spojrzenie na Morze Śródziemne rzadko bywa samodzielne $[\ldots]^{9}$.

Doświadczenie innego - tak charakterystyczne i istotne dla intelektualnego profilu Matvejevicia - pozwala wyeksponować we wspomnianych książkach różnorodność jako naturalną i uniwersalną właściwość ludzkiej egzystencji. Śródziemnomorza będącego „różnorodnością w jedności” nie postrzega jedynie jako mostu łączącego światy i cywilizacje, ale zwraca uwagę na obecne w nim podziały, przeciwieństwa i różnice. „Specyficzne cechy śródziemnomorskie nie wtapiają się bez reszty w inne całości, nie wchodzą we wszystkie związki Pomorza z kontynentem, Południa z Północą, Wschodu czy Zachodu z Południem"10 - zaznacza Matvejević, podkreślając, że te przeciwieństwa, które mogły i często stawały się przyczyną podziałów, często także naznaczały stare i nowe kultury, decydując o ich kształcie, profilu i wyjątkowości. A zatem Śródziemnomorze jest dla niego zmaganiem się z innościa, ale też otwarciem się na inność.

\section{Między Jugosławią a Europą Środkową}

Te głębsze kulturowo-cywilizacyjne ramy pisarstwo Matvejevicia zyskało bezpośrednio przed opuszczeniem przez niego Chorwacji ${ }^{11}$, a także już na emigracji (a więc od 1991 roku). Odszedł wówczas od twórczości, która bezpośrednio dotyczyła spraw polityczno-społecznych na rzecz twórczości ukazującej tożsamościową alternatywę. Nie oznacza to jednak, że całkowicie porzucił idee, o które zaciekle walczył właściwie przez całe życie, o czym świadczą jego liczne teksty publicystyczne, eseistyczne, odezwy i apele.

Wróćmy jednak do czasu, gdy Matvejević spierał się o jugoslavenstvo (jugosłowiańskość), w które wierzył, i przywołajmy jego poglądy na temat Europy Środkowej, do której podchodził z dużym dystansem. Niewątpliwie na stanowisko Matvejevicia odnośnie drugiej idei w dużym stopniu wpłynęła postawa samego Miroslava Krležy, z którym na temat tego konstruktu rozmawiał w przywołanych już kultowych rozmowach (Razgovori s Miroslavom Krležom, 1969). Zacytujmy odpowiedni fragment:

Centralna Evropa danas kao neka vrsta mixtum composituma za estetsko-morfološke diferencijacije apstraktna je mješavina koja ne govori mnogo više nego slične varijante: Centralna Amerika, Centralna Afrika ili Centralna Azija [...]. Naumannova parola o Centralnoj Evropi danas je formula tihe nostalgije za davnim danima kad je još vladala španjolska dinastija: Die schönen Tage

9 P. Matvejević, Brewiarz..., op. cit., s. 109.

10 Ibidem, s. 15.

11 O historii jego emigracji i postawie Matvejevicia jako emigranta piszę w tekście Predrag Matvejević: Jugosłowianin na emigracji, czyli między azylem i egzylem, „Pamiętnik Słowiański” 2011/2, t. LXI, s. 127-145. 
von Aranjuez sind vorbei... Don Juana od Austrije doduše nema, ali su Kafka, Rilke i drugi još uvijek Austrija... ${ }^{12}$

(Europa Środkowa jako pewnego rodzaju mixtum compositum w estetyczno-morfologicznym procesie różnicowania jest obecnie abstrakcyjnym połączeniem, które nie sugeruje niczego więcej niż pokrewne jej warianty: Ameryka Środkowa, Afryka Środkowa albo Azja Środkowa [...]. Slogan Naumanna o Europie Środkowej jest obecnie formułą cichej nostalgii za dawnymi czasami, kiedy władała hiszpańska dynastia: Die schönen Tage von Aranjuez sind vorbei... Don Juana de Austria wprawdzie nie ma, ale Kafka, Rilke i inni to wciąż Austria...).

Matvejević ten zdystansowany stosunek Krležy do Mitteleuropy postrzegał przez pryzmat jego młodzieńczych doświadczeń jako obywatela Austrii - obywatela cierpiącego z powodu przynależności do narodu cywilizacyjnie opóźnionego i podporządkowanego silniejszemu. Zupełnie odmienną od tej, bo w dużej mierze entuzjastyczną postawę względem tego wyobrażonego konstruktu reprezentowali w latach 80. XX wieku chorwaccy, a zwłaszcza słoweńscy intelektualiści. Matvejević dostrzega oczywiście atrakcyjność tej idei i rozumie możliwość powiązania kultury chorwackiej - pod względem kulturowym i geograficznym - z Europą Środkową, z jednym wyraźnym zastrzeżeniem. Otóż, nie może być dla niej usprawiedliwienia ,kad postaje alibijem da se manje bude u Jugoslaviji i ne suobraća s drugim jugoslavenskim kulturama onoliko koliko je moguće i korisno za svaku od njih"13 (kiedy staje się alibi dla mniejszej obecności w Jugosławii i mniejszej komunikacji z innymi jugosłowiańskimi kulturami w tym zakresie, w jakim jest to możliwe i korzystne dla każdej z nich). Wątpliwości, a nawet niechęć wobec podtrzymywania jugosłowiańskich związków, będąca - jego zdaniem - rezultatem ,iskrivljenih gledanja, opterećenih ideologijom" "14 (skrzywionych poglądów, obciążonych ideologią) przyczyniają się do zmniejszenia i tak już nadwątlonego wzajemnego zaufania.

Myślenie Matvejevicia i jego stanowisko względem jugosłowiańskości ilustruje spór z 1983 roku z Josipem Vidmarem, słoweńskim krytykiem literackim, eseistą i politykiem. Kością niezgody i przyczynkiem do sprzeciwu wobec jego poglądów stał się dla Matvejevicia spis ludności, w którym pojawiła się „,mogućnost da se pojedinci opredijele kao Jugoslaveni"15 (możliwość określenia siebie Jugosłowianinem); Vidmar uznał taką opcję za śmieszną. Dla autora Jugoslavenstva danas postawa taka była niezrozumiała - tym bardziej, że jeszcze w 1974 roku słoweński intelektualista przewidywał stworzenie jugoslavenske kulture (jugosłowiańskiej kultury), jeśli tylko przezwycięży się narodowe i kulturowe partykularyzmy, zwłaszcza w odniesieniu do historii. Matvejević tymczasem, uważając ten głos za nieadekwatny i nieodpowiedni w kontekście trudnej sytuacji, w jakiej znalazło się wspólne państwo, apeluje o potrzebę swego rodzaju solidarności. Ci intelektualiści serbscy, chorwaccy i słoweńscy, którzy swoim znaczeniem przekraczają granice własnych kultur narodowych, powinni odegrać istotną rolę w życiu publicznym, to znaczy pa-

12 P. Matvejević, Razgovori s Miroslavom Krležom, Zagreb 1969, s. 97-98.

13 Idem, Srednja Evropa, emigracija, književnost: Josef Škvorecký, [w:] J. Škvorecký, Mirákl: politički krimić, predgovor M. Kundera, prijev. D. Ruljančić, Zagreb 1987, s. 511.

14 Ibidem.

15 P. Matvejević, Akademiku Josipu Vidmaru (Zagreb, 28. II 1983), [w:] idem, Otvorena pisma, op. cit., s. 74 . 
trzeć na wspólną polityczną, społeczną i kulturalną rzeczywistość z ,jugoslavenskog gledišta"16 (jugosłowiańskiego punktu widzenia).

\section{Matvejeviciowska kultura dialogu (jeszcze jeden przykład)}

W swojej znaczącej książce zatytułowanej Otvorena pisma (Listy otwarte, 1985) Matvejević zwraca uwagę, że jugosłowiańskie środowisko kulturalne i literackie rozwijało się w dużej mierze na marginesie życia publicznego. Nie wszystkie wydarzenia, zjawiska i poglądy mogły zaistnieć oficjalnie z uwagi na sytuację społeczno-polityczną czy też wszechobecną cenzurę. Ujawniane później, konfrontowane z innymi świadectwami i odczytywane w nowych okolicznościach, często stawały się niezrozumiałe, pozbawione tak ważnej aktualności, choć z drugiej strony zyskiwały znaczenie dokumentów historycznych.

Specyfika i oryginalność wspomnianego dzieła wynika właśnie z obecnego w nim autentycznego żywiołu dyskusji, która w latach 80. XX wieku nie znajdowała sprzyjającej atmosfery w życiu publicznym. Płaszczyzną rozmowy dla Matvejevicia jest jugosłowiańska rzeczywistość, która na tle innych państw bloku wschodniego wyraźnie się odróżniała. Odrzucenie stalinizmu przez Titowską Jugosławię nie oznaczało jednak wolności od obecności jego śladów w polityce i kulturze. W zamierzeniu Matvejevicia zatem jego książka miała być zdecydowanym głosem sprzeciwu wobec tych ideologicznych zjawisk i figur.

Wyraźnie jednak przy tej okazji zauważa, że elity polityczne i intelektualne nie wykorzystały ideowego kapitału 1948 roku. Duma i samozadowolenie jakie towarzyszyło wybiciu się na swego rodzaju niezależność dosyć szybko ustąpiły miejsca partykularnym różnicom i podziałom, które uniemożliwiły normalne funkcjonowanie na arenie międzynarodowej. Życie intelektualisty, podważającego oficjalny porządek i dostrzegającego wewnętrzne problemy, stało się w Jugosławii trudne i problematyczne, gdyż - jak podkreśla Matvejević - „kritički duh je, danas i ovdje, obilježen negacijom”'17 (duch krytyki jest, tu i teraz, naznaczony negacją).

Powstałe z tradycji europejskiej lewicy i demokracji (Wolter i Emil Zola, Włodzimierz Lenin i Palmiro Togliatti) listy otwarte, składające się na całą książkę, były przez Matvejevicia wysyłane - z uwagi na interes państwa i społeczeństwa - tylko do rodzimych czasopism i gazet. Przyświecały im przy tej okazji cele i zamierzenia, które sam autor uważał za wynikające z poczucia elementarnej przyzwoitości:

Nastojao sam skrenuti pažnju na odgovornost prije nego na krivicu, na povredu prava a ne na oportuna opravdanja. Držao sam više do ravnopravnosti nego do hijerarhije, do ugleda zemlje nego do njezine ugroženosti. U pismima koja se obraćaju rukovodiocima ili ustanovama želio bih da se vide prijedlozi koje iznosim, a ne sama činjenica da im se na ovakav, u nas još uvijek neuobičajen način, obraćam ${ }^{18}$.

\footnotetext{
16 Ibidem, s. 73.

17 P. Matvejević, Slobodanu Mašiću..., op. cit., s. 10.

18 Ibidem, s. 11.
} 
(Próbowałem zwrócić uwagę raczej na odpowiedzialność niż winę, raczej na łamanie prawa niż na oportunistyczne uzasadnienia. Bardziej zależało mi na równouprawnieniu niż hierarchii, na reputacji kraju niż jej nadszarpnięciu. W listach skierowanych do rządzących albo instytucji życzyłbym sobie, aby były w nich widoczne sprawy, które podnoszę, a nie sam fakt, że w ten właśnie sposób, u nas wciąż uchodzący za niecodzienny, do nich się zwracam).

Taka postawa wobec podnoszonych przez niego spraw oraz problemów odwoływała również do kwestii moralności, a właściwie zasad moralnych przywoływanych w różnych listach. Podobnie zresztą jak literaturze, a zwłaszcza jej twórcom potrzebne są „,́wiczenia stylistyczne” (,stilske vježbe”) ${ }^{19}$, tak kultura i jej uczestnicy wymagają „ćwiczeń moralnych" („moralne vježbe” ${ }^{20}$. Ślad tego nastawienia, wyrażonego poza tym wprost i bez ozdobników, znalazł się także w podtytule całej książki, dopiełniając niejako jej ideowe i intelektualne ramy. Tu kryło się, oczywiście, pewne niebezpieczeństwo, z którego istnienia Matvejević zdawał sobie sprawę; chodziło przede wszystkim o ryzyko posądzenia o moralną czy etyczną wyższość piszącego, co z łatwością trywializowałoby całe przedsięwzięcie.

$\mathrm{Na}$ tym tle usprawiedliwiająco brzmią jego słowa na temat Miroslava Krležy i Ivo Andricia, którzy nie pisali listów otwartych. Wybrali - jego zdaniem - taki a nie inny typ relacji między twórcą i społeczeństwem; typ relacji, który wówczas był dla nich najkorzystniejszy. Obecnie taką postawę Matvejević jednoznacznie uznaje za niewystarczającą, a nawet szkodliwą. Sytuacja społeczna i polityczna, która stała się kontekstem jego książki wymagała innego podejścia, sprzeciwu wyrażonego innymi środkami. Tym bardziej że - jak zaznacza - granica sporu nie jest tak łatwa do uchwycenia:

U mnogim bitnim pitanjima ne slažem se s onima koje ovdje pokušavam braniti: branio sam ne njih, njihovo pravo na razliku. Ponekad su mi po mnogo čemu bliži oni kojima se suprostavljam. Takva su protuslovlja prirodna. Ne može se sve podijeliti na naše i njihovo. Naveo sam na početku Voltaireovu staru izreku: Protivim se onom što govorite, ali borit ću se svim svojim silama da to možete réci $i^{21}$.

(W wielu ważnych sprawach nie zgadzam się z tymi, których tutaj próbuję bronić: broniłem jednak nie ich, ale ich prawa do odmiennego zdania. Czasem są dla mnie pod wieloma względami bliżsi ci, przeciw którym występuję. Takie sprzeczności są naturalne. Nie można wszystkiego podzielić na nasze i ich. Przytoczyłem na wstępie stare powiedzenie Woltera: Nie zgadzam się z twoimi pogladami, ale po kres moich dni będe bronit twego prawa do ich głoszenia.)

Zwróćmy uwagę na charakterystyczny i wymowny dla całej intelektualnej spuścizny Matvejevicia wątek o jakim zaświadcza omawiana książka. Otóż, szerokim echem odbiła się zapoczątkowana w 1984 roku dyskusja Matvejevicia z wybitnym serbskim intelektualistą Dobricą Ćosiciem. Jako aktywny uczestnik i uważny obserwator życia publicznego ówczesnej Jugosławii Matvejević zwrócił się z apelem do Ćosicia o przedsięwzięcie kroków zmierzających do zdjęcia z repertuaru przedstawienia Kolubarska bitka (Bitwa nad

\footnotetext{
19 Ibidem.
}

20 Ibidem.

${ }^{21}$ Ibidem, s. 12. Autorem słów, na które powołuje się Matvejević i które są mottem jego książki w rzeczywistości nie jest Wolter; pochodzą one z fabularyzowanej biografii tego francuskiego myśliciela Przyjaciele Woltera (1906) napisanej przez Evelyn Beatrice Hall. 
Kolubara) powstałego na podstawie jego powieści Vreme smrti (Czas śmierci, 1972-1979). Przyczyną takiego ostrego stanowiska względem tego dzieła nie był jego autor, treść czy idea mu przypisana, a reakcje jakie sztuka wzbudziła wśród publiczności:

Nije ona sama po sebi toliko loša (ima čak i dramaturške vještine u Mihizovoj adaptaciji), ali pojednostavljuje djelo iz kojeg je istrgnuta i pobuđuje neprilične asocijacije i reakcije. Sam pisac, naravno, nije odgovoran za načine na koje se njegovo štivo čita. Znamo kako su sve tumačeni Vaši spisi, s koliko im se pristranosti ili tendencioznosti pristupalo. Kad sam, na predstavi Kolubarske bitke, čuo i vidio kako na vojvodin poklič Pomoz Bog junaci gotovo cijela sala gromoglasno odvraća Bog ti pomogao, osjetio sam se slično kao 1970-1971 u Zagrebu, kad su pri spomenu imena Zrinskoga i dr. pojedinci (i grupe) padale u nacionalni trans. Jedan glas iz publike nije se mogao uzdržati te je, u trenucima posebnog uzbuđenja, prekidao predstavu uzvicima Živela Srbija. (Za takve su ispade ovdje privodili na miliciju, što sigurno nije bilo najumnije). Neka žive i Srbija, i Hrvatska, i Jugoslavija, i svi ostali, ali...22

(Nie jest ona sama w sobie taka zła [adaptacja Mihiza odznacza się nawet pewną dramaturgiczną sprawnością], ale upraszcza dzieło, z którego została zaczerpnięta i wywołuje niewłaściwe skojarzenia i reakcje. Sam pisarz, oczywiście, nie jest odpowiedzialny za sposób w jaki odczytuje się jego twórczość. Wiemy jak interpretowane są wszystkie Pana teksty, z jaką stronniczością albo tendencyjnością do nich podchodzono. Kiedy na przedstawieniu Kolubarska bitka, słysząc i widząc jak na okrzyk generała Niech Bóg ma was w opiece, bohaterowie prawie cała sala gromko odpowiedziała Niech Bóg cię błogostawi, poczułem się podobnie jak w latach 1970-1971 w Zagrzebiu, kiedy tylko samo imię Zrinskiego i innych wywoływało u niektórych [a nawet w grupach] narodowy trans. Jeden głos z widowni nie mógł być powstrzymany, więc w momentach szczególnego podniecenia, przerywał przedstawienie okrzykami Niech żyje Serbia. [Do takich incydentów wzywano milicję, co z pewnością nie było najrozsądniejsze]. Niech żyje i Serbia, i Chorwacja, i Jugosławia, i wszyscy pozostali, ale...).

Matvejević odwołuje się przy tej okazji do niepisanego, ale obecnego w świadomości twórców jugosłowiańskich porozumienia co do tego, że ich twórczość nie może być instrumentalnie i politycznie wykorzystywana w bieżącym dyskursie publicznym. Istnienie takiej zgody dotyczącej ram i granic funkcjonowania literatury powoduje, że pisarz staje się jednak odpowiedzialny za swoje dzieło - również w tym zakresie jak może być odczytywane i rozumiane. Taki wniosek - wbrew wcześniejszym zapewnieniom Matvejevicia można przecież wyciągnąć z jego zdecydowanej uwagi:

Ali, kad bi svatko od nas inscenirao vlastitu prošlost, uznosio je i veličao prema potrebama i prilikama, ona bi nas još više i fatalnije udaljavala jedne od drugih. (Zamislite samo kako bi mogle izgledati predstave s nacionalnim temama u nekim našim sredinama i, pogotovo, kako bi na njih gledale druge sredine. $)^{23}$

(Ale, gdyby każdy z nas inscenizował własną przeszłość, wychwalał ją i wywyższał w zależności od potrzeb i okoliczności, ona by nas jeszcze bardziej i tragiczniej oddalała od siebie nawzajem. [Niech Pan tylko pomyśli jak mogłyby wyglądać spektakle podejmujące narodowe tematy w niektórych naszych środowiskach, a zwłaszcza jak by na nie patrzyły inne środowiska]).

\footnotetext{
${ }^{22}$ P. Matvejević, Dobrici Ćosiću (Zagreb, 16. IV 1984), [w:] idem, Otvorena pisma..., op. cit., s. 58.

${ }^{23}$ Ibidem, s. 59.
} 
Główny zarzut Matvejevicia dotyczy więc właśnie istoty samego dzieła Ćosicia, które przekracza granice modelu powieści historycznej i staje się - jak to ujmuje Matvejević „romanom historije"24 (powieścią historii).

Ten zdecydowany i konkretny (gdyż odnoszący się do szczegółowego problemu), ale w formie i treści wyważony, apel Matvejevicia spotkał się jednak z ostrym atakiem ze strony samego Dobricy Ćosicia, który bardzo jednoznacznie odebrał jego sens. Stał się on dla niego przyczynkiem do wykładu swoich poglądów na temat jugoslovenstva (jugosłowiańskości) i serbskiej historii. Odpowiedź Ćosicia nie pozbawiona była także bezpośrednich zarzutów pod adresem samego Matvejevicia, którego wystąpienie przeciw sobie wpisywał w szerszy kontekst nabrzmiewających sporów i konfliktów ideologicznych w Jugosławii. Zwracając się do Matvejevicia (nieco ironicznie przy tym nazywając go Jugosłowianinem), zrównuje go de facto z tymi, którym nie przeszkadza ani sama sztuka, ani reakcje publiczności, tylko właśnie serbska historia w niej przedstawiona. Zarzucając mu zatem, że nie dostrzega antywojennej, antymilitarystycznej, wolnościowej i demokratycznej retoryki jego dzieła, lokuje go po stronie serbofobów i szowinistów ${ }^{25}$.

Zapoczątkowana w ten sposób dyskusja pomiędzy tymi ważnymi dla środowiska literackiego i artystycznego intelektualistami zyskała także kolejne, nie mniej interesujące odsłony. Ton tego - jak podkreśla Matvejević - dialogu opierał się na wzajemnej tolerancji i obustronnym szacunku, a więc na tych wartościach, które według niego powinny wyznaczać podstawy każdej rozmowy i każdego sporu w jugosłowiańskiej rzeczywistości. Niemniej jednak dialogiczna relacja Matvejevicia i Ćosicia, przedstawicieli bądź co bądź odpowiednio chorwackiego i serbskiego środowiska (choć pierwszy z nich bardzo protestował przed tego typu - narodowościowym właśnie - odczytywaniem ich relacji), nie zyskiwała bezwarunkowego uznania, a nawet spotykała się z próbami swoistej manipulacji. Właśnie w tych kategoriach należy postrzegać wykorzystanie ich dyskusji w zagrzebskim czasopiśmie „Polet” (1984), gdzie posługując się wybranymi fragmentami ich listów, reprezentujących wzajemne poszanowanie rozmówców, przedstawiono ich jako ,politycznych kochanków" (politički ljubavnici): Matvejevicia jako chorwackiego nacjonalistę, Ćosicia zaś jako reprezentanta wielkoserbstwa ${ }^{26}$. Zmanipulowana, przekłamująca sens ich listów ,informacja" nie była tylko wydarzeniem prasowym - stała się także, a może przede wszystkim, wyrazem zaostrzającego się sporu ideologicznego, i w tym sensie zatruwającego życie publiczne Jugosławii w połowie lat 80 .

\section{Perspektywa ostatnich lat}

W ostatnich latach Matvejević często wypowiadał się na aktualne, często także kontrowersyjne tematy. W swoim szkicu Mediteran na pragu novoga milenija (Śródziemnomorze

24 Ibidem.

${ }_{25}$ Por. D. Ćosić, Predragu Matvejeviću (Beograd, 4. V 1984), [w:] P. Matvejević, Otvorena pisma..., op. cit., s. 63.

${ }^{26}$ Por. P. Matvejević, Dobrici Ćosiću (Zagreb, 22. V 1984). Post scriptum, [w:] idem, Otvorena pisma..., op. cit., s. 71. 
na progu nowego milenium $)^{27}$ pisał na przykład, że Śródziemnomorze cierpi na wszechobecne podziały i nie może samo z siebie zabezpieczyć własnego istnienia. Bagaż ogromnego dziedzictwa, przeszłych stuleci i dziejowych zaszłości wywoływać może poczucie pewnego dyskomfortu, widocznego w potrzebie ustosunkowania się do jego znaczenia dla teraźniejszości. Śródziemnomorze nie stanowi dziś jedności, zresztą przez większą część swojego istnienia było podzielone. Dziś jest podobnie, nad czym ubolewa Matvejević. Będąc nawet człowiekiem urodzonym nad brzegiem Morza Śródziemnego, można doświadczyć tej zamykającej i dzielącej tendencji. Nie trzeba przekonywać, że urodzić się w Algierii, Albanii czy Syrii, to nie to samo, co urodzić się we Francji czy we Włoszech. Ostatni czynnik mówi o typowym dla nowoczesności rozbiciu tożsamości człowieka, którego świadomość określa się w pespektywie różnorakich odniesień: narodowych, społecznych, wyznaniowych, kulturowych.

W zakończeniu książki Kruh naš Matvejević zadaje z kolei pytanie, które z jednej strony uznać należy za wyraz jego zaangażowania i poczucia wagi, jaką dostrzega w literaturze, $z$ drugiej zaś za echo pojawiających się idealistycznych dążeń poetów, pisarzy i artystów chcących zmieniać świat: „Co może uczynić literatura, żeby chleba było dla wszystkich i dla każdego?"28 Pióro poety czy pisarza zmienia jednak świat co najwyżej na papierze. A książki, niestety, nie są chlebem powszednim, którym pożywiają się i z którego czerpią inspiracje miliony. Dlatego jego odpowiedź jest smutnym rozrachunkiem z kulturą, zwłaszcza literatury z rzeczywistością, którą się żywi, i z iluzją, którą tworzy: „Może tylko wyrazić troskę i niepokój" ${ }^{29}$. W książkach Matvejevicia - jak słusznie zauważa Robert Bréchon - więcej jest pytań niż odpowiedzi, nie ma w nich wyraźnej afirmacji i końcowego, rozstrzygającego akcentu ${ }^{30}$.

Tylko te dwa przykłady, wybrane z tekstów napisanych w ostatnich latach, pokazują, że Matvejević miał świadomość ogromu wyzwań, jakie stoją przed Europą. Zawarte w nich obserwacje nabierają szczególnego znaczenia w kontekście aktualnych problemów naszego kontynentu, zwłaszcza kryzysu imigracyjnego.

Matvejević aktywnie uczestnicząc w życiu publicznym Chorwacji, otwarcie i przy tym zazwyczaj bardzo krytycznie wypowiadał się na bieżące tematy polityczne i społeczne, czym przysporzył sobie wielu wrogów, samego siebie natomiast lokował tym samym w opozycji do oficjalnego dyskursu. Jego nieprzejednanie w tych sprawach spowodowało, że stał się „wrogiem publicznym numer jeden”, co jeszcze raz potwierdziło starą maksymę, że trudno być prorokiem we własnym kraju. O skali wrogości wobec Matvejevicia świadczyło nie tylko jego wyklęcie $\mathrm{z}$ akademickich i intelektualnych środowisk w Chorwacji, ale także zinstytucjonalizowana krucjata przeciw jego osobie i jego poglądom. Kulminacyjnym momentem tych wydarzeń było orzeczenie chorwackiego sądu z 2010 roku podtrzymujące wcześniej zasądzoną dla niego karę więzienia za obarczenie moralną odpowiedzialnością za wojnę w Bośni i Hercegowinie takich pisarzy jak Momo Kapor czy Ivan Aralica. Sprawa ta odbiła się szerokim echem w Europie, a wielu zachodnioeuropejskich intelektu-

\footnotetext{
${ }^{27}$ Tu korzystam z tekstu, który otrzymałem od P. Matvejevicia drogą elektroniczną.

28 P. Matvejević, Kruh naš, Zagreb 2009, s. 140.

29 Ibidem.

30 R. Bréchon, Predrag Matvejević: građanin jedne nenalazive Evrope, prev. N. Ivić, [w:] Predrag Matvejević. Književnost-kultura-angažman, prired. S. Roić i N. Ivić, Zagreb 2003, s. 56.
} 
alistów wystosowało apele i listy otwarte namawiające władze chorwackie do cofnięcia tego wyroku.

Prasowe i medialne informacje o odejściu Predraga Matvejevicia donosiły o śmierci wielkiego intelektualisty, wybitnego humanisty i jednego z najpoczytniejszych chorwackich autorów w Europie. Wreszcie w odniesieniu do jego osoby, jego twórczości i działalności na pierwszy plan wybijały się wyrazy uznania, a nie tylko epitety, jakich mu ostatnimi czasy nie szczędzono. Lakoniczność tych przekazów często jednak wyrażała swoisty dystans. Niemniej wypada mieć nadzieję, że ideowy i intelektualny testament Matvejevicia zostanie odpowiednio doceniony i wykorzystany nie tylko w Chorwacji.

\section{Bibliografia}

Bréchon R., Predrag Matvejević: građanin jedne nenalazive Evrope, prev. N. Ivić, [w:] Predrag Matvejević. Književnost-kultura-angažman, prired. S. Roić i N. Ivić, Zagreb 2003, s. 47-58.

Ćosić D., Predragu Matvejeviću (Beograd, 4. V 1984), [w:] P. Matvejević, Otvorena pisma. Moralne vježbe, Zagreb 1985, s. 60-66.

Jančar D., Eseje, przeł. J. Pomorska, wyb. i wstęp K. Czyżewski, Sejny 1999.

Kermauner T., Recenzija Matvejevićevih „Otvorenih pisama”, prev. I. Cesar, [w:] P. Matvejević, Otvorena pisma. Moralne vježbe, Zagreb 1985, s. 189-193.

Kubik D., O „pragnieniu źródła” - judeochrześcijańskie i śródziemnomorskie korzenie Europy w eseistyce Predraga Matvejevicia, [w:] Źródła humanistyki europejskiej, t. 3, red. K. Korus, Kraków 2010, s. 15-28.

Kubik D., Predrag Matvejević: Jugostowianin na emigracji, czyli między azylem i egzylem, „Pamiętnik Słowiański" 2011/2, t. LXI, s. 127-145.

Kubik D., O potrzebie tożsamości w czasach nowoczesnych: tożsamość kulturowa Zbigniewa Herberta i Predraga Matvejevicia, „Pamiętnik Słowiański” 2009, t. LIX, z. 1, s. 33-53.

Magris C., Filologia morza, [w:] P. Matvejević, Brewiarz śródziemnomorski, przeł. D. Ćirlić-Straszyńska, Sejny 2003, s. 5-10.

Matvejević P., Akademiku Josipu Vidmaru (Zagreb, 28. II 1983), [w:] P. Matvejević, Otvorena pisma. Moralne vježbe, Zagreb 1985, s. 73-79.

Matvejević P., Brewiarz śródziemnomorski, przeł. D. Ćirlić-Straszyńska, Sejny 2003.

Matvejević P., Dobrici Ćosiću (Zagreb, 16. IV 1984), [w:] P. Matvejević, Otvorena pisma. Moralne vježbe, Zagreb 1985, s. 58-60.

Matvejević P., Dobrici Ćosiću (Zagreb, 22. V 1984). Post scriptum, [w:] P. Matvejević, Otvorena pisma. Moralne vježbe, Zagreb 1985, s. 66-72.

Matvejević P., Jugoslavenstvo danas: pitanja kulture, Zagreb 1982.

Matvejević P., Kruh naš, Zagreb 2009.

Matvejević P., Mit nacije i sablasti nacionalizma. Nacionalna kultura i mondijalizacija, „Rukovet: časopis za književnost, umetnost i kulturu" 2006, br. 1-3, s. 32-34.

Matvejević P., Prema novom kulturnom stvaralaštvu, II prošireno izd., Zagreb 1977.

Matvejević P., Razgovori s Miroslavom Krležom, Zagreb 1969.

Matvejević P., Slobodanu Mašiću, nezavisnom izdavaču (Zagreb, 9. V 1985), [w:] P. Matvejević, Otvorena pisma. Moralne vježbe, Zagreb 1985, s. 9-13.

Matvejević P., Srednja Evropa, emigracija, književnost: Josef Škvorecký, [w:] J. Škvorecký, Mirákl: politički krimić, predgovor M. Kundera, prijev. D. Ruljančić, Zagreb 1987, s. 511-517.

Ostolski A., Lewica po stronie prawdy, [w:] S. Žižek, Kruchy absolut. Czyli dlaczego warto walczyć o chrześcijańskie dziedzictwo, przeł. M. Kropiwnicki, wstęp J. Kutyła, Warszawa 2009, s. 167-173. 
DAMIAN KUBIK

\section{The right to be different \\ - the concept of engagement in Predrag Matvejević's writing (an essay) \\ Summary}

The article attempts to analyse the concept of engagement (commitment) in the books of Predrag Matvejević, a remarkable Croatian intellectual. Starting with a short presentation of his nonconformist views on political, social and cultural issues, the article focuses on highlighting the main features of his fight for the right to be different, one of the most important rights in the eyes of an intellectual.

Keywords: Predrag Matvejević, concept of engagement (commitment), the right to be different. 